Saudi Journal of Business and Management Studies Abbreviated Key Title: Saudi J Bus Manag Stud ISSN 2415-6663 (Print) |ISSN 2415-6671 (Online) Scholars Middle East Publishers, Dubai, United Arab Emirates Journal homepage: http://scholarsmepub.com/sjbms/

Original Research Article

\title{
Entrepreneurship, Conditions and Benefits an Analysis of the Elements That Allows to Develop it
}

\author{
Liliana Álvarez-Loya, J. Emilio Méndez-González*, Ma. Guadalupe Maldonado-Iglesias, Enrique Guzmán Nieves \\ Fulltime Teachers in Business and Entrepreneurship Development in Accounting and Management Faculty- Autonomous University of Chihuahua \\ UACh, México
}

\author{
DOI: $10.36348 /$ sjbms.2019.v04i12.009 \\ | Received: 08.12.2019 | Accepted: 22.12.2019 | Published: 30.12.2019
}

*Corresponding author: J. Emilio Méndez-González

\section{Abstract}

Entrepreneurship in Mexico is a trigger for the national economy, universities seek to generate the conditions so that their students have the necessary preparation and are able to start a company, generate jobs and participate in the generation of the Gross Domestic Product (GDP) of the country. However, not only does academic training generate the platform for the development of companies, but they interfere with a series of circumstances that arise in this research. The present study seeks to determine the conditions that are presented in university students to undertake, their characteristics and how they perceive the benefits for that process. It is important to note that $60 \%$ of students of all levels are willing to start a business and agrees that the same percentage has a history of entrepreneurship in their family, for this reason it can be considered that the family is an important influence on the choice career in business areas; passion is another aspect that is present in entrepreneurial students and the type of business they seek to generate is innovative. As for the benefits that are visualized as entrepreneurs, economic freedom stands out and being their own boss. To start a business, they consider that financing issues are the most important, followed by training and professional preparation.

Keywords: Entrepreneurship Development, Entreprenurial Passion, Entreprenurial Profile, Innovation, Entreprenurial Skills.

Copyright @ 2019: This is an open-access article distributed under the terms of the Creative Commons Attribution license which permits unrestricted use, distribution, and reproduction in any medium for non-commercial use (NonCommercial, or CC-BY-NC) provided the original author and source are credited.

\section{INTRODUCTION}

In many countries the participation of micro, small and medium enterprises represents a large percentage of their Gross Domestic Product (GDP), to say that the economic spill and the engine of the same is born in the decision to form a company, to generate sources of Direct and indirect employment that ultimately becomes a country's economy. The GEM [1] defines entrepreneurship as: "any attempt to create new businesses or new businesses, such as self-employment, a new business organization or the expansion of an existing business, by an individual, a team of individuals or an established business".

For its part, the OECD [2] defines entrepreneurship as a phenomenon that seeks to "generate value through the creation or expansion of economic activity, identifying and exploiting new products," which also tells us about innovation. Necessary as a desirable quality in the profiles of the entrepreneur.

Being an entrepreneur, not only offers benefits to the entrepreneur, but also supports the same community in which it is inserted, with the creation of jobs, promoting the economy and helping to "minimize the adverse and structural factors that oblige people to leave their country of origin "UNESCO [3], within this same document in goal 4.4 it is established by 2030 to increase the number of young people and adults trained... to access employment, decent work and entrepreneurship, still highlighting plus the importance it has.

The economy is based on resources or based on innovation, in the case of Mexico according to the GEM [1], for point 1 there is a percentage of $36.38 \%$ of 
adults aged 18 to 64 who perceive opportunities, $50.07 \%$ that $\mathrm{He}$ believes he has the knowledge and skills to undertake, $28.40 \%$ with fear of failure and $50.67 \%$ who see entrepreneurship as a good career choice.

In Mexico, according to Guerrero, Urbano, Ramos, Ruiz-Navarro, Neira, \& Fernández-Laviada [4], $21 \%$ of the students have already created a company, $42 \%$ have enterprising parents and of these, $27 \%$ are or have been entrepreneurs, mentions that $25 \%$ of men have been entrepreneurs against $17 \%$ of women, the IDB [5] says that the profile of creative entrepreneurs in Latin America: they are mostly men $(61,8 \%)$ and in its minority women (38.2\%). The average age of the creative entrepreneur is 35 years, and $90.4 \%$ have university studies, these differences are clear to understand that the first study is specific to Mexico, while the second includes all of Latin America.

According to Guerrero et al., [4] University students in Mexico have a very positive attitude towards entrepreneurship, they perceive it as an enriching professional option that will give satisfactions in their working life, $49.7 \%$ of these, has started a company, $54.4 \%$ believe they have the knowledge and skills necessary to undertake, and $29.8 \%$ feel fear of failure in their projects, $65 \%$ say they want to undertake in the short term and $50 \%$ say they have received some training in this regard, data that are consistent with the information already mentioned of the GEM [1] and presents small differences.

This last data, from those who have received training in this regard, contrasts with what the IDB says [5], according to the data of this study, entrepreneurs in general learned to do business "on the fly", that is, during The process of gestation of your company, that is, that despite having received some training or training in their professional training, this was not adequate or was insufficient.

Different authors Guerrero et al., [4] and González et al., [6], mention as important factors: age, schooling, sex, profession of parents, among others to make the decision to become an entrepreneur or decide not to try.

As said by Fernández et al., [7] the variables of gender, age and occupation of the parents do not influence the student's decision to create a company, contrasting with the statements made before.

Some of the most important factors to decide to undertake are: The greatest motivation to be an entrepreneur is the satisfaction that would have to have your own company, the image and the importance of being an entrepreneur in society, the influence exerted by the media, personal independence and personal or family security.
Among the factors that limit entrepreneurship, there are natural elements such as the total ignorance of the steps to follow, in addition to the fear of failure is presented as one of the main limitations to undertake, economic risks, limited time for other activities and tax charges.

Leyva et al., [8] in their study they set out to measure the relationship that personal, intellectual and social skills have with the entrepreneurial achievement skills perceived by undergraduate students, for which they established the following criteria: Within personal skills the self-confidence, within the intellectuals the ability to identify problems and within the Social teamwork

Students' perception of entrepreneurship is intimately related to their own personal, sociocultural and cognitive skills and abilities, even with their maturity, as Salvatorio [9] affirms at an older age, it is more punctual and objective in related assessments. With the evaluation of the fulfillment of objectives in a company.

In the entrepreneurial profile, two variables are mentioned, which is formed of the attitudes, aptitudes and abilities of the individual, as well as an entrepreneurial spirit, which will be developed within your stay as a university student. These skills have to be complemented with another group of abilities such as: values of the individual, creativity, initiative, selfconfidence, energy and work capacity, perseverance, leadership, acceptance of risk, the need for achievement, Change tolerance and problem management, Kantis 2010, Pablo-Martí and GarcíaTabuenca 2006, cited by Leyva [8].

The Faculty of Accounting and Administration has a "Business Incubator" that has been endorsed for the fifth consecutive year by the body that regulates entrepreneurship in Mexico; The National Institute of Entrepreneurs, this Incubator seeks to generate business training through training, business scenario development and linking with different sectors to support entrepreneurs in their initial phase. In its last issue, it started with 34 projects, of which 27 completed the process, this incubator opens a biannual call and is at the service of both the community and the students of the Faculty of Accounting and Administration.

In the 2018-2019 school year, the Autonomous University of Chihuahua [10], the Faculty had the entrance of 975 students and re-entry of 2,312, that is to say, it has a total of 3,285 active students, who seek an administrative economic formation and are within reach the incubator services including with specific scholarships offered to its students.

In advanced semesters, students as a whole must study a subject called Entrepreneurship 
Development, which seeks to generate entrepreneurship in students by developing skills necessary to start a company. However, it is up to each university student to make the decision to form a company.

The present study seeks to analyze the benefits of undertaking university students of one of the Faculties with the largest student population of the Autonomous University of Chihuahua, the School of Accounting and Administration, its analysis is divided into three stages, students from first to third semester, from fourth to seventh and from sixth to ninth, seeking to compare the way they see entrepreneurship at the beginning of their instruction, in the development of their academic preparation and in the last stage of business training.

This theme represents for Mexico $51 \%$ of its Gross Domestic Product (GDP), and the generation of $72 \%$ of the generation of jobs through micro, small and medium entrepreneurs, so that higher level institutions adapt new strategies of training for the contribution to the economy in our country.

Casson, 1982, cited by González Sánchez et $a l .$, [6] has defined the entrepreneur as "someone who specializes in making judicious decisions regarding coordination in the use of scarce resources", under this definition a new element appears, decision making based on value judgments, since they are focused on the use of resources that are considered scarce.

The FCA of the UACH, has the business incubator, which in its most recent intervention began with 34 projects, of which 27 culminated the process and also has the recognition by the National Institute of Entrepreneurs (INADEM) endorsed by the Ministry of Economy of the Government of the Republic.

It is noteworthy to see that $90.4 \%$ of these entrepreneurs, have university studies, at the UACH School of Accounting and Administration, 975 new students and 2,312 reentry students were registered, for a total of 3,285 students in total, in the 2018-2019 school year Autonomous University of Chihuahua, 2018.

Therefore, it is the commitment of the university to create the most favorable conditions for the development of entrepreneurship, wishing that this work begins to trace the path to identify the perception of its students about entrepreneurship and the skills, attitudes and knowledge necessary for their development.

According Guerrero et al., [4] the areas where more entrepreneurship is carried out are the social sciences has the advantage with $24 \%$, they mention that Mexican students have a more positive attitude towards entrepreneurship, they also see in their universities a positive environment that develops their abilities to identify business opportunities", under this assumption, universities have a great commitment to continue generating new and better programs that promote this spirit of economic growth.

In the tax burdens, there is also a greater ignorance on the part of the entrepreneurial students since they do not have experience in this regard, it is even possible to affirm that the companies subject to analysis, whether administered by students or entrepreneurs, are not the most appropriate and in the Most of the cases are carried out empirically, which shows the importance of identifying this perception on the subject, working on it and establishing the mechanisms that contribute to the resolution of this problem.

\section{MATERIAL AND METHODS}

The nature of the research was mixed, with an inductive method beginning with the individual study of the facts and formulating general conclusions and proposals. It was a non-experimental research that was carried out in the FCA of the UACh, during the semester August-December 2019. With a descriptive, transectional design, since it identified a situation and new knowledge is generated.

The population of interest students of the different degrees of the FCA of the UACh, from the semester from August to December 2019.

The sample framework was determined in accordance with the profile of the FCA-UACh in terms of Entrepreneurship and Entrepreneurial Intention, this being the one focused on relating more to if there is a history of entrepreneurship in my family, if they was started a business, about what is the main condition that I consider an entrepreneur must have, what kind of business would they like to start, about the types of support they consider to exist for entrepreneurs and finally what they consider is the main barrier to start a business.

Variables, the evaluation of the survey indicators to determine differences in the variables that constitute some constructs about entrepreneurship.

The type of sampling was probabilistic, since the observation or sampling units had the same opportunity to be selected. The results of this research can be generalized to the rest of the school population.

Sample Size, based on the above, the same number of surveys were conducted students; between the first and third semester 161, between fourth and sixth 206 and between seventh and ninth semester 239 to give a total of 606 surveys.

The measuring instrument for this research was a questionnaire, in which the project indicators were 
Liliana Álvarez-Loya et al; Saudi J Bus Manag Stud, Dec., 2019; 4(12): 919-925

evaluated and the Statistical Package for the Social Sciences (SPSS) program was used to encode information and statistical analysis of the Information,

through Tables and graphs to present the results of the research.

\section{RESULTS AND DISCUSSION}

Table-1: Results of the Research

$\begin{array}{ll}\text { 1st to 3th } & \text { Semester } \\ \text { 4th to 6th }\end{array}$

7th to 9 th

There is a history of entrepreneurship in my family

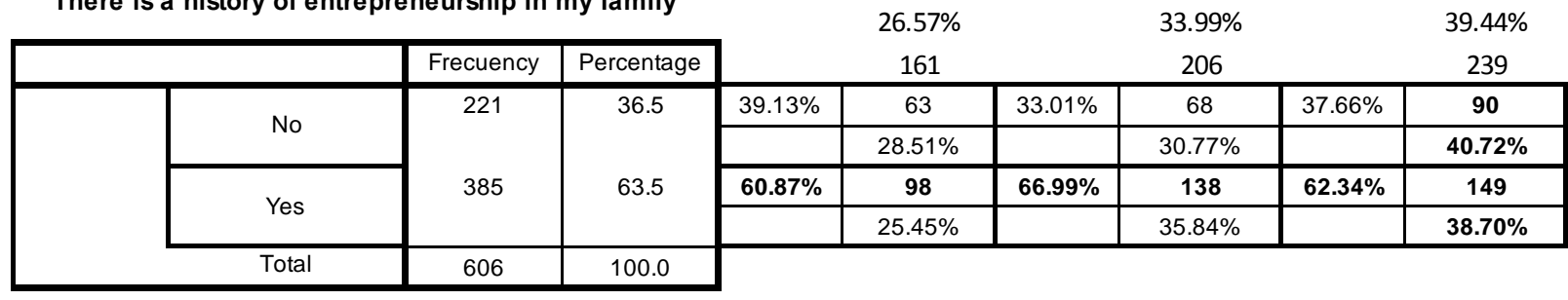

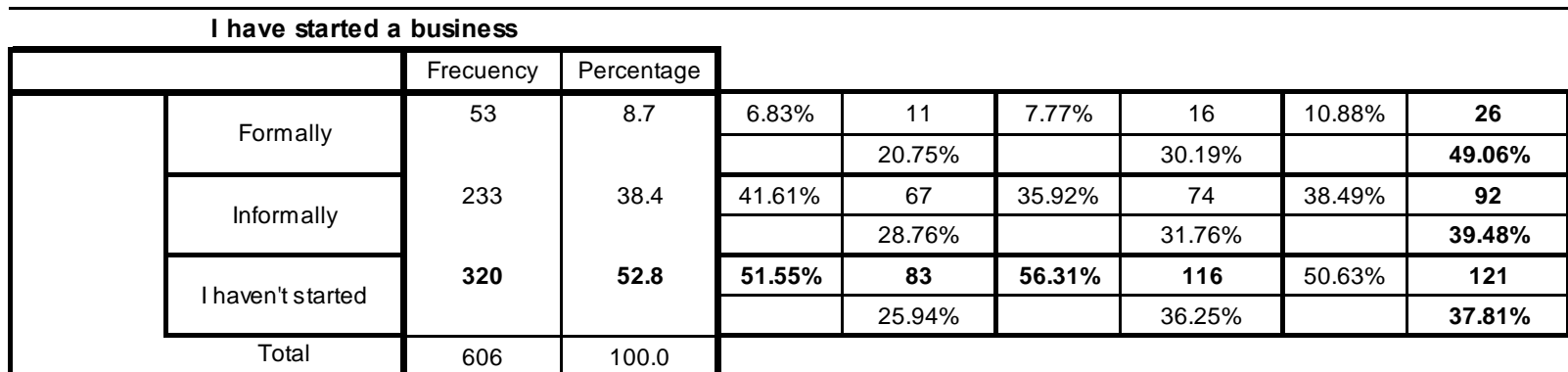

What is the main condition that I consider an entrepreneur must have

\begin{tabular}{|c|c|c|c|c|c|c|c|c|}
\hline & Frecuency & Percentage & & & & & & \\
\hline \multirow{2}{*}{ Family Support } & \multirow[t]{2}{*}{25} & \multirow[t]{2}{*}{4.1} & $4.35 \%$ & 7 & $4.85 \%$ & 10 & $3.35 \%$ & 8 \\
\hline & & & & $28.00 \%$ & & $40.00 \%$ & & $32.00 \%$ \\
\hline \multirow{2}{*}{$\begin{array}{c}\text { Management \& } \\
\text { Negotiation capacity }\end{array}$} & \multirow[t]{2}{*}{152} & \multirow[t]{2}{*}{25.1} & $21.12 \%$ & 34 & $23.79 \%$ & 49 & $28.87 \%$ & 69 \\
\hline & & & & $22.37 \%$ & & $32.24 \%$ & & $45.39 \%$ \\
\hline \multirow{2}{*}{$\begin{array}{l}\text { Knowledge about } \\
\text { business }\end{array}$} & \multirow[t]{2}{*}{112} & \multirow[t]{2}{*}{18.5} & $14.91 \%$ & 24 & $19.90 \%$ & 41 & $19.67 \%$ & 47 \\
\hline & & & & $21.43 \%$ & & $36.61 \%$ & & $41.96 \%$ \\
\hline \multirow{2}{*}{ Passion } & \multirow[t]{2}{*}{317} & \multirow[t]{2}{*}{52.3} & $59.63 \%$ & 96 & $51.46 \%$ & 106 & $48.12 \%$ & 115 \\
\hline & & & & $30.28 \%$ & & $33.44 \%$ & & $36.28 \%$ \\
\hline Total & 606 & 100.0 & & & & & & \\
\hline
\end{tabular}

What kind of business would I like to start?

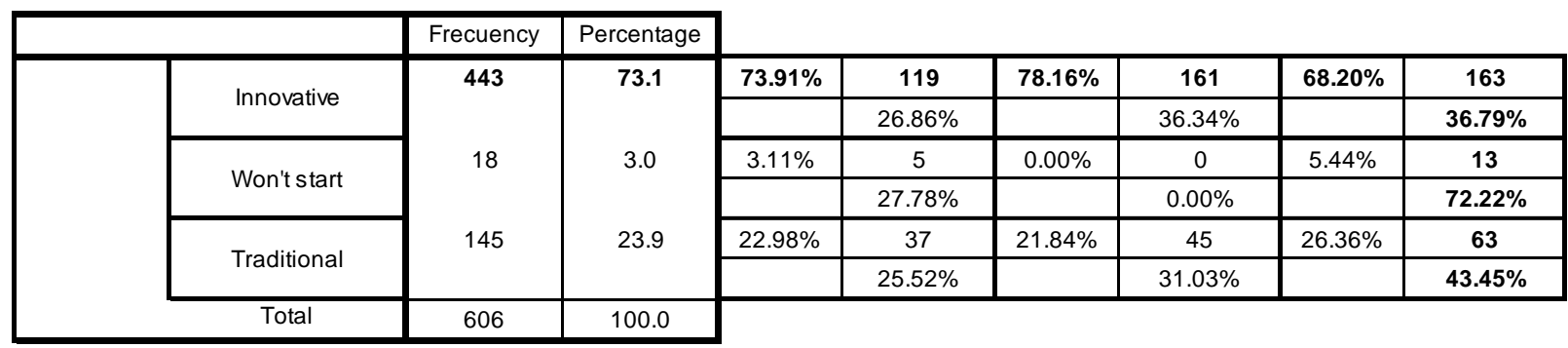


The main reason I would like to start a business is

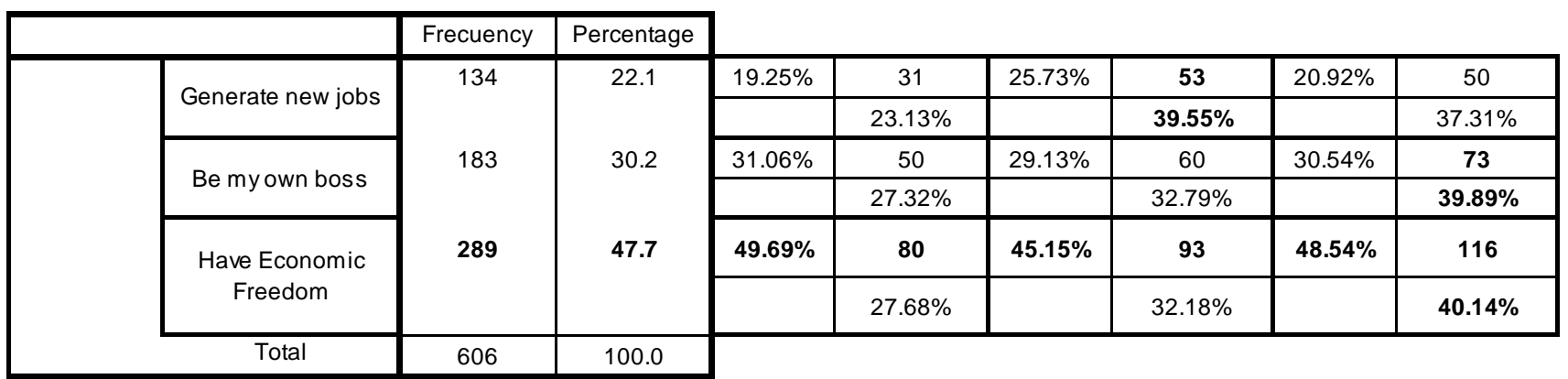

\begin{tabular}{|c|c|c|c|c|c|c|c|c|}
\hline \multicolumn{3}{|c|}{$\begin{array}{l}\text { What types of support do I consider to exist for } \\
\text { entrepreneurs? }\end{array}$} & & & & & & \\
\hline & Frecuency & Percentage & & & & & & \\
\hline \multirow{2}{*}{ Both } & \multirow[t]{2}{*}{1} & \multirow{2}{*}{.2} & $0.00 \%$ & 0 & $0.00 \%$ & 0 & $0.42 \%$ & 1 \\
\hline & & & & $0.00 \%$ & & $0.00 \%$ & & $100.00 \%$ \\
\hline \multirow{2}{*}{ Advising } & \multirow[t]{2}{*}{243} & \multirow[t]{2}{*}{40.1} & $38.51 \%$ & 62 & $50.97 \%$ & 105 & $31.80 \%$ & 76 \\
\hline & & & & $25.51 \%$ & & $43.21 \%$ & & $31.28 \%$ \\
\hline \multirow{2}{*}{ Financial } & \multirow[t]{2}{*}{316} & \multirow[t]{2}{*}{52.1} & $57.14 \%$ & 92 & $42.72 \%$ & 88 & $56.90 \%$ & 136 \\
\hline & & & & $29.11 \%$ & & $27.85 \%$ & & $43.04 \%$ \\
\hline \multirow{2}{*}{ Neither } & \multirow[t]{2}{*}{46} & \multirow[t]{2}{*}{7.6} & $4.35 \%$ & 7 & $6.31 \%$ & 13 & $10.88 \%$ & 26 \\
\hline & & & & $15.22 \%$ & & $28.26 \%$ & & $56.52 \%$ \\
\hline Total & 606 & 100.0 & & & & & & \\
\hline
\end{tabular}

What I consider to be the main barrier to start a business

\begin{tabular}{|c|c|c|c|c|c|c|c|c|}
\hline & Frecuency & Percentage & & & & & & \\
\hline \multirow{2}{*}{ Lack of Attitude } & \multirow[t]{2}{*}{61} & \multirow[t]{2}{*}{10.1} & $9.32 \%$ & 15 & $12.62 \%$ & 26 & $8.37 \%$ & 20 \\
\hline & & & & $24.59 \%$ & & $42.62 \%$ & & $32.79 \%$ \\
\hline \multirow{2}{*}{ Lack of Guidance } & \multirow[t]{2}{*}{81} & \multirow[t]{2}{*}{13.4} & $11.18 \%$ & 18 & $13.59 \%$ & 28 & $14.64 \%$ & 35 \\
\hline & & & & $22.22 \%$ & & $34.57 \%$ & & $43.21 \%$ \\
\hline \multirow{2}{*}{ Lack of Resources } & \multirow[t]{2}{*}{266} & \multirow[t]{2}{*}{43.9} & $41.61 \%$ & 67 & $43.69 \%$ & 90 & $45.61 \%$ & 109 \\
\hline & & & & $25.19 \%$ & & $33.83 \%$ & & $40.98 \%$ \\
\hline \multirow{2}{*}{ Fear to Fail } & \multirow[t]{2}{*}{198} & \multirow[t]{2}{*}{32.7} & $37.89 \%$ & 61 & $30.10 \%$ & 62 & $31.38 \%$ & 75 \\
\hline & & & & $30.81 \%$ & & $31.31 \%$ & & $37.88 \%$ \\
\hline Total & 606 & 100.0 & & & & & & \\
\hline
\end{tabular}

Source: Field Survey conducted during Aug-Dic 2019

Analyzing the results, it is possible to determine which most important relationship between the analyzed variables are those determined to more than $60 \%$ of the students of all levels are determined to start a business; also more than $60 \%$ of respondents have a history of entrepreneurship in their family, so it is possible to infer that the choice of a career related to business is influenced by their support or family reference; Another important relationship is the condition that considers that entrepreneurs must have, and is without a doubt, the passion for the ongoing project; The type of business that students evaluate the most they can undertake, is some with innovative characteristics, rather than traditional, which denotes a great influence of progress and new trends; the main reason why students are running a business is to have economic freedom, then to become their own bosses;
Another point of analysis, is given in the perception of external opportunities and supports that they perceive and is given with the relevant result in financial needs and professional training or preparation, finally, the lack of resources, it is considered that the most important barrier, more than in the attitude and lack of professional or academic preparation.

\section{CONCLUSION}

Situation of entrepreneurship in Mexico

In Mexico, according to Guerrero et al., [4] $21 \%$ of the students have already created a company, $42 \%$ have entrepreneurial parents and of these, $27 \%$ are or have been entrepreneurs.

While Guerrero et al., [4], mentions that $25 \%$ of men have been entrepreneurs against $17 \%$ of women, 
IDB [5] says that the profile of creative entrepreneurs in Latin America: they are mostly men $(61.8 \%)$ and in its minority women $(38.2 \%)$. The average age of the creative entrepreneur is 35 years, and $90.4 \%$ have university studies, these differences are clear to understand that the first study is specific to Mexico, while the second includes all of Latin America.

The perception that each individual has about entrepreneurship can be determined in three indicators, namely, according to Serida et al., [11].

1. The consideration that in the next six months there will be conditions to start a business

2. The perception of having the knowledge and skills necessary to undertake

3. Fear of failure.

On the other hand, the perception of society as a whole is also valued:

1. Perception of entrepreneurship as a good career choice

2. The status and prestige granted by starting a business

3. The media attention given to entrepreneurship

These factors will vary as you pass from one stage to another.

A Chihuahua designer said: "No one at any school gives you topics on how to deal with the client [or administrative points]. There should be more information ... [about] the administration of a creative business. Or someone who give us the recipe."

Leyva-Carreras et al., [8] in their study they proposed to measure the relationship between personal, intellectual and social skills with the entrepreneurial achievement skills perceived by undergraduate students, for which they established the following criteria: Within personal skills, self-confidence, within the intellectuals the ability to identify problems and within the Social teamwork.

- Intellectuals.

- $\quad$ Ability to identify problems.

- Social.

- Teamwork.

Two variables are mentioned, the entrepreneurial profile, which is formed of the attitudes, aptitudes and abilities of the individual, as well as an entrepreneurial spirit, which will be developed within your stay as a university student. These skills have to be complemented with another group of abilities such as: values of the individual, creativity, initiative, selfconfidence, energy and work capacity, perseverance, leadership, acceptance of risk, the need for achievement, Change tolerance and problem management.

In that research, through surveys to measure personal, intellectual and social skills, the authors were able to conclude that the achievement in entrepreneurship is based on trust skills, ability to identify problems and teamwork, however, they also do Note the need for the University of Sonora, Mexico to implement a profile model for the development of entrepreneurial skills.

For its part, the Inter-American Institute for Cooperation on Agriculture (IICA) [12] identifies ten characteristics of entrepreneurial behavior, grouped into three areas:

Achievement oriented features:

1. Search for opportunities and constant initiative

2. Persistence

3. Compliance

4. Search for efficiency and quality

5. Take calculated risks

Planner features:

6. Set goals

7. Information search

8. Systematic planning and monitoring

Power characteristics:

9. Persuasion and support networks

10. Self confidence and independence

These skills are directly related to those mentioned above and there are direct coincidences such as self-confidence, risk and planning.

According to Serida et al., [11], this would demonstrate that entrepreneurial perceptions and attitudes would respond more to cultural and political aspects of a region rather than to economic models and the level of development of countries.

It is also important to consider that, although the percentage of students in the first semesters they undertake is high, they do so informally; they are the students of the last semesters, who undertake mostly in a formal way.

Being able to conclude like this, with aspects to emphasize:

Focus the academic teaching of innovation and focus the entrepreneurial passion in the generation of innovative and formal companies that allows generation of new jobs, also in a formal way and with the benefits of law.

\section{ACKNOWLEDGEMENTS}

Special thanks are made to the Director of the Business Center of the Faculty of Accounting and Administration of the Autonomous University of Chihuahua and his Business Incubator, Engineer Carlos Espino for the facilities provided and the information provided for conducting this research. 


\section{REFERENCES}

1. GEM. (s.f.). How GEM defines entrepreneurship. [Internet] Available December 13, 2019, at Global Entrepreneurship Monitor: https://www.gemconsortium.org/wiki/1149

2. OECD. (2017). Entrepreneurship at a Glance $2017 . \quad$ doi: http: //dx.doi.org/10.1787/entrepreneur_aag-2017-en

3. UNESCO. (2019). Global Education Monitoring Report 2019: Migration, Displacement and Education. Building Bridges, not Walls. Paris: UNESCO. [Internet] Available December 13, 2019, from https://unesdoc.unesco.org/ark:/48223/pf00003674 36/PDF/367436en.pdf.multi

4. Guerrero, M., Urbano, D., Ramos, A. R., RuizNavarro, J., Neira, I., \& Fernández-Laviada, A. (2016). Entrepreneurial profile of the university student. University Entrepreneurship Observatory in Spain. Madrid: Crue Spanish UniversitiesRedEmprendia-CISE. [Internet] Available December 13, 2019, at: https://www.crue.org/Documentos\%20compartido s/Publicaciones/Observatorio\%20de\%20Emprendi miento\%20Universitario/20161201_Observatorio $\% 20 \mathrm{de} \% 20$ Emprendimiento\%20Universitario_inf orme_web.pdf

5. IDB. (2018). Undertake an orange future. [Internet] Available December 13, 2019, at: The Inter-American Development Bank: https://publications.iadb.org/publications/spanish/d ocument/Emprender-un-futuro-naranja-Quincepreguntas-para-entender-mejor-a- creativeentrepreneurs-in-Am\% C3\% A9rica-Latina-y-elCaribe.pdf

6. González Sánchez, R., Torres Preciado, V., \& Tinoco Zermeño, M. Á. (2017). Empirical analysis of the determinants of entrepreneurship in university students: The case of the University of Colima in Mexico. Economy and Society, XXI (36), 43-59. [Internet] Available December 13, 2019 , at: https://www.redalyc.org/articulo.oa?id=510/51052 064003
7. Fernández-Laviada, A., Rueda Sampedro, M. I., \& Herrero Crespo, Á. (2014). Study of the entrepreneurial attitude of university students of the faculty of CC.EE. and business of Cantabria. Memories of the Ibero-American Congress of Science, Technology, Innovation and Education. Buenos Aires, Argentina. [Internet] Available December 13, 2019, at: http://www.aeca1.org/pub/on_line/comunicaciones _xvicongresoaeca/cd/36f.pdf

8. Leyva-Carreras, A. B., Alcántara-Castelo, J. R., Espejel-Blanco, J. E., \& Coronado-García, M. A. (2019). Training of the entrepreneurial profile in higher education at the University of Sonora. School of Business Administration Magazine (86). [Internet] Available at: https://doi.org/10.21158/01208160.n86.2019.2293

9. Salvatorio, A. M. (2012). Personality and intelligence characteristics associated with entrepreneurs in an institution of higher education. Doctoral thesis. Mexico: National Autonomous University of Mexico. [Internet] Available December 13, 2019, at: https://132.248.9.195/ptd2012/mayo/0680699/Inde x.html

10. Autonomous University of Chihuahua. (2018). UACH Retrieved on December 12, 2019, from Basic Statistics: Administration 2016-2022: [Internet] Available at: https://uach.mx/assets/media/publications/2017/10 /143_agenda-estadistica/estadistica-basica-20182019.pdf

11. Serida, J., Guerrero, C., Alzamora, J., Borda, A., \& Morales, O. (2017). Global entrepreneurship monitor: Peru 2106-217. Retrieved on December 13, 2019, from ESAN Graduate School of Business:

https://www.esan.edu.pe/publicaciones/2017/10/12 /GEM\%202016-2017\%20VF.pdf

12. IICA. (2009). Young entrepreneurs: Committed to the Sustainable Development of Rural Territories. (Beltrán, M. O. Ed.) Quito, Ecuador: InterAmerican Institute for Cooperation on Agriculture. 